\title{
A HISTORICAL/POLITICAL JUSTIFICATION FOR THE NEED FOR MULTICULTURAL CITIZENSHIP EDUCATION AND EDUCATORS: THE CASE OF TURKEY AND THE EUROPEAN UNION ${ }^{1}$
}

\begin{abstract}
Summary. Citizenship education, with its focus on equality, human rights and social justice for all, has become one of the central instruments for improving civic knowledge among world citizens and for supporting the development of more democratic states based on the rule of law. Like many other nations, the Turkish Republic, a country in negotiation with the European Union for possible membership, has placed great emphasis on citizenship education since the time of its foundation. This study takes on the question of whether Turkey provides adequate citizenship education as it is understood in and framed by the European Union's education and training strategic plan, known as Education and Training 2020 - particularly in light of its focus on promoting multiculturalism and appreciation for diversity in an increasingly heterogeneous society. To this end, the study first provides some background information on the general status of citizenship education in Europe. This is followed by a description of the current framework as it is implemented in Turkey, which has historically included a homogenizing aspect, stressing unity rather than diversity. Finally, some recommendations are made concerning why Turkey needs further development in terms of a multicultural perspective on citizenship education, including the education of multiculturally competent teachers.
\end{abstract}

Keywords: Turkey, Democracy and Citizenship Education, Nation State, European Union, Education and Training 2020.

\section{Introduction}

Green (2013) identifies three major historical dynamics that have been influential in the process of establishing national systems in countries in which deep nationbuilding periods have been observed. Briefly, those dynamics are (1) the existence of external military threats that have led such countries to produce strong nationalistic reactions, (2) major internal transformations caused by a successful struggle for national independence, and (3) state-led reform programs that aim to gain a place within developed countries (Green, 2013). According to Green (2013), education, or specifically, the emergence of national education

\footnotetext{
${ }^{1}$ A small portion of this study was presented at the International EJER Congress at Istanbul University, 24-26 April 2014.
} 
A HISTORICAL/POLITICAL JUSTIFICATION FOR THE NEED FOR MULTICULTURAL CITIZENSHIP EDUCATION AND EDUCATORS: THE CASE OF TURKEY AND THE EUROPEAN UNION

systems in countries that experienced a nation-building period in their history, are also associated with this fact. In other words, developing a national education system with a primary intention of accelerating the nation-building process is a major feature of those states that faced a task of national reconstruction following an independence war. In fact, as discussed by Davies et al. (2005), establishing a national identity based on citizenship requires citizenship education, especially during the age of the nation-state. As Anderson (1983) observes, those countries have focused on an imagination of national community and established their national education systems based upon national history, language and culture.

Yet, since the second half of the twentieth century, nation-states have changed in light of some major global events, and it has been argued that citizenship education has been developing in line with these changes. According to Tambini (2001), for example, national citizenship has declined due to factors such as economic globalization, cultural denationalization, migration (especially labor mobility), and transnational institutions. Essentially, all these reasons and the like can be summed up under a single factor, perhaps the key factor that has influenced various things that were more nationalistic before: globalization. Accordingly, Davies et al. (2005) argue that although education still serves the nation-state, a new perspective on citizenship is required, since a new idea of citizenship has been generated by globalization.

Within this line of history, an important transnational institution or supranational organization can be identified as the European Union. While being centrally influential in many aspects of the social, political, and economic structures of its members, the EU has also played an essential role in shaping education systems in many countries in the contemporary era, including nonmember states, as well. The emphasis on citizenship education, which is placed by both the EU and other major supra-national organizations, and which focuses on democracy and human rights from perspectives of multiculturalism, has globally been one of the central instruments for improving civic knowledge among citizens and developing more democratic states based on the rule of law.

In this regard, multicultural citizenship education has been of a great concern for developed countries in general and for the European Union (EU) in particular, especially over the last two decades (Gelūnas, 2015). Like many other states, Turkey, a country in negotiation with the EU for possible membership, has 
Raşit ÇELIK

placed particular importance on citizenship education since its foundation. Turkey was established based on a perspective of the nation-state, and its educationsystem was structured in accordance with that perspective. Education, particularly citizenship education, played a crucial role in creating a national identity and an understanding of citizenship among the members of the society, which can be explained by the political attitude of the age of the nation-state as described above. Yet, in line with what has been observed in the global arena, citizenship education in Turkey has been influenced and modified by some global developments, especially since the 1990s. In this regard, this study takes on the question of whether Turkey provides adequate citizenship education in the sense that it is understood in and framed by the EU's education and training strategic plan, currently the Education and Training 2020 (ET 2020). Accordingly, the study first provides a brief history of citizenship education in the EU, with an emphasis on multiculturalism as understood in the contemporary importance. This is followed by a discussion about why Turkey needs to develop a multicultural perspective on citizenship education, along with the need for preparing multiculturally competent teachers.

\section{EU and Citizenship Education}

\section{A Brief History}

Past decades have witnessed an increasing concern about citizenship education in the West in general and in Europe in particular, primarily because of the growing effect of supra-national political developments. In fact, according to Kerr and Lopes (2008), this growing interest has been stimulated by global factors, such as a decline in democratic participation in politics on the part of younger citizens, the fall of the old Soviet regime, terrorist attacks in various countries around the world, and enlargement of the European Union. But how have the European states been influenced by those factors with respect to both their political structure and education systems, particularly in terms of citizenship education?

The European Union, as it is named today, retained the primary features of the nation-state until 1980 (Mann, 1993). But in the subsequent decades, such characteristics of the European Union have also changed in line with global 
A HISTORICAL/POLITICAL JUSTIFICATION FOR THE NEED FOR MULTICULTURAL CITIZENSHIP EDUCATION AND EDUCATORS: THE CASE OF TURKEY AND THE EUROPEAN UNION

events. Of course, such structural and political change has also influenced the overall view on education, and on citizenship education, in particular. As stated by Grek et al. (2009), events such as the Treaty of Rome in 1957, the Single Act in 1987, the Maastricht Treaty in 1992, and Amsterdam in 1997 set the stage for the historical development of the European Union's educational policy. Particularly, the Maastricht Treaty in 1992 gave the Union legal power to control all policy areas (Mann, 1993) and thus legal authority over education, for the first time (Holford, 2008).

In 1997, Education for Democratic Citizenship and the Human Rights Education Project were initiated. The Project's terrain was explored between 1997 and 2000; its policies were clarified between 2001 and 2004. The year 2005 was declared as the European Year of Citizenship through Education, and the focus was on the project's implementation between 2006 and 2009 (Kerr \& Lopes, 2008). Moreover, within this timeline, in 2002, the Council of the European Union approved the Education and Training 2010 work programme based on common educational objectives; this established for the first time solid framework for the education and training policies of the EU (Council of Europe 2002, 2009). This framework was updated by the ET 2020, which was declared in 2009 and which specifies educational objectives and strategies up to the year 2020 for member states (Council of Europe, 2009). The European Commission was required to evaluate the impact of the ET 2020, focusing on the period between 2009 and 2014, after which a new phase was planned for 2015 in light of the Commission's evaluation report.

\section{Citizenship Education and Multiculturalism}

Before proceeding further, it may be appropriate to provide detailed information about this historically uninterrupted educational concern and put a particular emphasis on the focus on citizenship education and multiculturalism. In 1997, the Council of Europe (1997) clearly declared that citizenship education has a crucial role in preparing the young for being fully cooperating members of a democratic society, and thus in overcoming the main obstacles to "building a freer, more tolerant and just European society" (p. 2). 
Raşit ÇELIK

Accordingly, the Council of Europe's Committee of Ministers adopted the Declaration and Programme on Education for Democratic Citizenship Based on the Rights and Responsibilities of Citizens in 1999 and encouraged member states to:

promote democratic citizenship based on the maintenance and further realisation of human rights and fundamental freedoms; make education for democratic citizenship based on the rights and responsibilities of citizens an essential component of all educational, training, cultural and youth policies and practices (Council of Europe, 1999, para. 14).

In 2000, the Lisbon European Council set the strategic goal for the European Union for the next decade and invited the Education Council "to undertake a general reflection on the concrete future objectives of education systems" (European Council, 2000, para. 27). In the following year, the Education Council adopted a report and submitted to the European Council, which listed concrete common future objectives for member states. Such report identified, among others, "supporting active citizenship, equal opportunities and social cohesion" as a common objective (Education Council, 2001, para. 2.2.3). Consequently, in 2002, the Council of the European Union approved the first solid work programme on education and training up to the year 2010. As Holford (2008) stresses, European Union's focus on active citizenship since the Lisbon 2000 agreement has enabled citizenship education to be a central element of the policy agenda. Currently, the objectives and principles of citizenship education are defined by and conducted in accordance with the European Union's ET 2020 programme. The ET 2020 takes its roots from the Lisbon strategy and is the next period after the ET 2010. In fact, following the Lisbon Strategy, the European council adopted Europe 2020 as a new strategy focusing on promoting smart growth across the Union (European Council, 2010).

What, then, are the current objectives of citizenship education under the ET 2020? The Council of the European Union (2009) first emphasizes the substantial contribution of education and training to achieving the objectives of the Lisbon strategy, and then states that "in the period up to 2020, the primary goal of European cooperation should be to support further development of education and training" (p. 3). In doing so, the Council provides a framework, ET 2020, to realize this end. The ET 2020 clarifies four strategic objectives: "making 

EDUCATION AND EDUCATORS: THE CASE OF TURKEY AND THE EUROPEAN UNION

lifelong learning and mobility a reality, improving the quality and efficiency of education and training, promoting equity, social cohesion and active citizenship, and enhancing creativity and innovation including entrepreneurship at all levels of education and training" (Council of European Union, 2009, p. 3). From the perspective of citizenship education, the third objective is of importance, since it identifies the principles and values that are considered to be crucial for the success of the programme; the ET 2020 encourages member states to follow the principles and values in accomplishing the objectives. In this sense, citizenship education is framed as promoting active citizenship, multicultural dialogue, democratic values, respect for human rights, positive interaction with others, and sensitivity to all kinds of discrimination. It is expected to advance citizenship education in member states in line with these values and principles, and to achieve the general objectives of the ET 2020 programme, by the year 2020 .

Obviously, the Lisbon strategy provides a milestone in the history of citizenship education in the EU. The report from the Education Council that was delivered to the European Council in 2001 states that, in accomplishing the objectives of the Lisbon strategy, education and training systems should enable people to "accept that racism and intolerance have no place ... [and] discrimination on any ground - such as gender, religion, colour or ethnic origin is unacceptable" (Education Council, 2001). The role of citizenship education in promoting social justice has also been emphasized by an understanding of multiculturalism. In the same report, the Council stressed the importance of learning "skills required in an increasingly international and multicultural society (Education Council, 2001). This notion of tolerant multicultural citizenship education also required taking into account the related multilingual concerns. Accordingly, the Council also highlights that European societies are now more diversified and multilingual and "foreign language teaching should reflect this in order to realize a sustainable development across the states (Education Council, 2001). Briefly, the values of tolerance, equality, and diversity have been promoted by the notion of citizenship education and embraced by the EU since the Lisbon strategy, which has led to restructuring of the main understanding of citizenship education through a perspective on multiculturalism and multilingualism. Today, multiculturally oriented citizenship education, with the 
Raşit ÇELIK

support of principles and values framed by the ET 2020, is expected in European education.

In short, citizenship education has been a main policy issue since the EU centralized active citizenship since the 2000s. With the implementation of the Education and Training programmes, the scope of citizenship education has become more concrete. It now is defined with certain fundamental values and principles, such as multicultural dialogue and positive interaction with others, which are seen essential for the wellbeing of pluralistic democracies in the era of supra-national organizations. Doubtless, such progress signifies the importance of developing a contemporary perspective on citizenship education with a focus on multicultural elements. In other words, multicultural citizenship education appears to be a necessity for states that aim to participate in the circle of developed democracies.

\section{Citizenship Education in Turkey}

\section{Background}

A look at the history of the Republic of Turkey in light of the above discussion reveals a similar pattern. In other words, the Turkish Republic was established based on a clear concept of the nation-state that is based on a single history, language, religion and culture. Accordingly, developing a national education system was a primary goal during the first years of the Republic as a means to guarantee a modern state, with new generations devoted to the state and nation (Çelik, 2012).

It may be easier to illustrate the development of citizenship education in Turkey by dividing it into a few distinct phases. According to Keser et al. (2011), creating a modern citizenry for the newly established Republic was an important concern beginning in 1923, as promoting democratic values was central to citizenship education following the adoption of the multi-party system in 1950 . After 1980, the definition of nation was based upon concepts such as national and historical unity and national sovereignty; and the period following Turkey's European Union candidacy (declared in 1999) appears to be the current phase. 

EDUCATION AND EDUCATORS: THE CASE OF TURKEY AND THE EUROPEAN UNION

From an alternative perspective, as Üstel (2004) argues, a communitarian sense of citizenship was promoted in text books until 1950s. During the 1960s, however, active and participatory citizenship was promoted in textbooks, rather than the previous notion of duty-based citizenship. However, during the $1970 \mathrm{~s}$ and 1980s, citizenship education once again took on a duty-based aspect, primarily because of military involvement in politics. Finally, following the 1980 coup in Turkey, textbooks placed clear emphasis on national unity based on nationalistic features. In any event, according to Çayır and Gürkaynak (2008), citizenship education in Turkey during all of these periods shared a common characteristic; namely, a cross-curricular element that stresses nationalist and duty-based features.

\section{Citizenship Education and Multiculturalism}

Beyond these historical phases, however, becoming an official candidate state to the EU has considerably influenced citizenship education in Turkey. Previously, with the influence of the United Nations' (1994) declaration of the Decade for Human Rights Education between 1995 and 2005, a Citizenship and Human Rights Education course was planned beginning in 1995 and put into practice in 1998 in the seventh and eighth grades. This course which focused more on human rights issues in seventh grade, put emphasis on citizenship and national concerns (Çayır \& Bağlı, 2011; Çayır and Gürkaynak, 2008). However, although basic rights and liberties as derived from universal human rights were included in this course, according to Gök (2004), top priority was given to national security over human rights; thus, emphasis was placed on the rationale for limiting citizens' rights when needed. Additionally, according to İnce (2012), instead of providing students with the underlying justification and principles of universal human values, this course represented the state as a developed democracy for propagandistic reasons. Consequently, this course fell short of helping students to develop appropriate conceptions of human rights and citizenship in pluralistic democracies. It is also clear that multicultural aspects of education were not included in this course.

As an outcome of the 2005 curriculum reform in Turkey, it was decided in 2008 that citizenship would be incorporated as a cross-curricular element into 
Raşit ÇELIK

different courses, such as history and social science, and that the Citizenship and Human Rights Education course would be abandoned. However, with the input of the European Union, it was decided in 2010 that citizenship would again be included as an independent course. Subsequently, Citizenship and Democracy Education became a requirement for the eighth grade beginning in the 2011-2012 academic year. This course adopts a civilian approach and has removed the militaristic emphasis on the importance of national security and military power against internal and external threats to the state. Citizenship and Democracy Education course takes citizenship from an approach that is more globally developed when compared to the previous citizenship education course and provides notions of democratic citizenship and global citizenship (Elkatmış, 2013).

However, according to Çayır (2011), it still falls short of providing an appropriate notion of pluralistic democracy, because this course characterizes Turkey as a single social structure and emphasizes civic duties toward the nation, disregarding cultural differences and placing little emphasis on constitutional principles and political institutions. Hence, it can be clearly argued that multicultural aspects of citizenship education have not been taken into account in that course, although it was promoted by the EU in accordance with the values, principles, and goals defined in the education programme discussed above, as supported by Çelik's (2013) assertion that multicultural issues are often neglected in Turkish public schooling.

Later, in light of the decisions made in 2012 and 2013, it was decided that this course would be taught in the fourth grade, instead of the eighth grade. Additionally, it was decided that an elective course, Law and Justice, would be offered for the sixth and seventh grades; and another elective course, Democracy and Human Rights was offered for high school students beginning with the 2014-2015 academic year. A close look at the Citizenship and Democracy Education course, which appears to be the only required course on citizenship among these courses, may help to evaluate and compare the objectives and principles with those of the ET 2020 as outlined above. 
A HISTORICAL/POLITICAL JUSTIFICATION FOR THE NEED FOR MULTICULTURAL CITIZENSHIP EDUCATION AND EDUCATORS: THE CASE OF TURKEY AND THE EUROPEAN UNION

\section{Citizenship and Democracy Education Course Examined}

In accordance with the principles of the Turkish education system, as defined in the Basic Law of National Education, the Citizenship and Democracy Education course aims to contribute to the realization of a stable and democratic society. As defined in this Law, one of the basic principles of Turkish national education is Democracy Education. It is also stated that students are to be provided with a notion of democracy and knowledge of statecraft, promoting a sense of responsibility among the nation's youth in order to realize and sustain a free and democratic social order. To this end, the curriculum guide of the Citizenship and Democracy Education course suggests providing students with an understanding of democracy, knowledge of the state and government, and a sense of responsibility. Accordingly, the curriculum is organized under four themes: the person as valuable, the culture of democracy, rights and liberties, and responsibilities and duties. The general aims of this course are defined as developing independent, tolerant, and responsible citizens who interact with others in accordance with democratic ways of life and who contribute to furthering the development of democracy in Turkey. Moreover, the skills and values that are to be developed in students in this course include, for example, critical thinking, comprehension of continuity and social change, reconciliation, social cohesion, sensitiveness to discrimination, altruism, toleration, empathy, respect for differences, responsibility, freedom, equality, peace and justice. These values and skills are distributed in the curriculum in accordance with the four themes.

So far, the values and principles promoted in the Citizenship and Democracy Education course appear to be quite consistent with the values and principles emphasized in the ET 2020 programme. For example, respect for differences, justice and sensitivity to discrimination, as well as valuing democratic ways of life and advancement of democracy, are central to both the course and the programme. However, one thing that appears to be problematic is the emphasis on the theme of responsibilities and duties. One third of the total course hours are allocated to this theme, which signifies a conceptual gap between the Citizenship and Democracy Education course and a projected citizenship education as suggested in the ET 2020 programme. Therefore, it may 
Raşit ÇELIK

be argued that the Citizenship and Democracy Education course conceptualizes democracy as largely concerned with duties and responsibilities. Despite the fact that this course aims to generate a culture of democracy and promote a list of values and principles that are central to the contemporary notion of developed democracy, such course's approach to democracy appears to be limited. It also signifies that the long-lasting concerns - including, for example, creating devoted citizens and highlighting national features, as mentioned above - continue preventing Turkey from developing a contemporary perspective on citizenship education and thus from advancing a contemporary culture of democracy. Such characteristics appear to be still underlying elements of citizenship education in Turkey. In sum, it must not be surprising for one to find almost no emphasis in that course on diversity, multiculturalism, social cooperation, toleration, and other values as defined by the ET 2020, which exemplifies the current notion of citizenship education in the country.

\section{Conclusion}

As stressed, Turkey's history is not independent of what has been observed in the global arena. The Turkish Republic, established as a nation-state, has been evolving into a more diversified one. As the above discussion suggests, Turkey needs to develop new functions as a nation-state, although it does not need to abandon its fundamental characteristics. Developing a contemporary notion of the citizen and of citizenship education appears to be a main concern, since Turkey is a developing democracy and aspires to become a full-fledged democratic society in line with its long-lasting aim to become a member of the EU.

As with many other policy areas, the EU promotes a clear strategic plan for member states in terms of educational policy. However, it does not require each member state to apply the same policy; instead, it only provides a general framework and identifies common objectives. In this sense, while a member state may pursue EU's general educational objectives, it may develop and implement its own education policy based on its unique social, political, and cultural needs. Considering citizenship education, in particular, a member state is allowed to formulate its own policy while being consistent with general objectives specified by the EU. In fact, as Ichilov (2013) stresses, "there is no single version of 

EDUCATION AND EDUCATORS: THE CASE OF TURKEY AND THE EUROPEAN UNION

citizenship, and that can be many diverse and different formulations of the citizenship principle in different social contexts and cultural traditions" (p. 23). In France, for example, the effects of globalization, immigration, and cultural and religious plurality have led educators to think more about citizenship education in light of concerns such as cultural diversity, social cohesion, toleration, and also religious education (Saint-Martin, 2013). Accordingly, discussions on citizenship education in France focus mostly on equal opportunity and integration (Côté et al., 2013). Moreover, while approaches to citizenship education in France generally adopt a more centralized school system and try to promote belief in the Republic, approaches in Sweden and England favor teaching objective civics, rather than inculcating patriotism and loyalty to the state (Côté et al., 2013). Similar differences can also be found in the approaches to citizenship education in Greece, Germany, and England (Faas, 2011).

From this perspective, taking Turkey as a potential member of the EU and as one who has been pursuing a centenarian goal of being a distinguished member of the circle of contemporary developed civilizations, it appears to be essential for the country to update and enhance its approach to citizenship education in order to develop citizens with a contemporary notion of the rule of law and culture of democracy. As seen in other countries, it is not necessary for Turkey to abandon its traditional approach to citizenship education, which, for example, prioritizes loyalty to the state and nation. However, it seems necessary to assign appropriate meanings to the values and principles listed in the curriculum guide of the citizenship education course. It is obvious that Turkey has carried out considerable reforms in citizenship education, especially during the 1990s and 2000s. However, most of those changes during that period remained structural, rather than conceptual (Çayır, 2009; Keser et al., 2011). A look at the current situation also reveals the same fact. Therefore, a citizenship education supported by conceptually adequate values and principles appears to be necessary in order to generate a citizenry that is capable of shouldering responsibility for taking Turkey to the place it deserves in the global arena.

In order to realize this, developing multicultural citizenship education appears to be necessary. As discussed above, historical and political developments in the global arena indicate that nations aiming at participating in the supra-national organizations need to reorganize their education systems, 
Raşit ÇELIK

especially regarding the way they provide citizenship education. However, issues of multicultural education have not been given sufficient weight in Turkish literature (Başbay \& Bektaş, 2009), even though both religious and secular circles in general accept and value the multicultural structure of Turkish society (Çelik, 2008).

Given these concerns, it is important for scholars to consider working on some essential issues of multiculturalism and multicultural education from contemporary perspectives. In particular, the concepts of tolerance, diversity and multiculturalism are to be thoroughly examined, and a clear notion of tolerant multicultural citizenship education must be reached in line with the most contemporary principles and values supported in the global arena. As discussed above in the case of the EU, this concern should also be emphasized in teacher education, especially with respect to multilingual concerns. Both education of foreign language teachers and foreign language teaching in general are to be discussed within a similar perspective that takes into account the fact that multilingually and culturally diverse structures of contemporary societies are inevitable. As emphasized, it is important for realizing a sustainable development of contemporary pluralistic societies. In short, developing an approach to multicultural citizenship education and a related approach to foreign language teaching and teacher education from perspectives of the values of diversity, equality, and tolerance appear to be crucial for contemporary pluralistic societies that aim at becoming a member of the circle of developed democracies.

To conclude, it can be argued that educating multiculturally competent teachers is crucial to achieving effective reforms in citizenship education as understood within the perspective discussed above. Without producing competent teachers prior to making structural changes in the education system, the desired goals are less likely to be achieved, as evidenced by the reforms in citizenship education carried out during the 1990s and 2000s. In this sense, in order to bring about effective reforms, changes must be made not only on a structural level, but also on a conceptual level. That fact emphasizes once more the necessity of developing an adequate approach to teacher education from a perspective of multiculturalism, before citizenship education in Turkey can be aligned with the contemporary values and principles as defined above. 
A HISTORICAL/POLITICAL JUSTIFICATION FOR THE NEED FOR MULTICULTURAL CITIZENSHIP EDUCATION AND EDUCATORS: THE CASE OF TURKEY AND THE EUROPEAN UNION

Of course, this last statement requires a further discussion as to what kind of educational approach is to be taken in teacher education. For instance, it is critical that teacher candidates experience authentic multicultural environments to genuinely comprehend the importance of multicultural education. To do so, teacher candidates need to have the opportunity to visit educational institutions in various societies where multicultural values and democratic ways of life align with the principles mentioned above. This also requires teacher candidates to have multilingual communication skills, which also stresses the necessity of multilingual teacher education. However, before this can take place, an appropriate approach to teacher education from a perspective of multiculturalism, as well as a clear definition of the aims of multicultural education, must be delineated.

\section{References}

Anderson, B. (1983). Imagined communities: Reflections on the origin and spread of nationalism. London: Verso.

Başbay, A., \& Bektaş, Y. (2009). International environment and teacher competencies in the context of multiculturalism. Education and Science, 34(152), 30-43.

Côté, I., Sundström, M. R., \& Sannerstedt, A. (2013). 'The state of debate': A media analysis of the debates on liberalization and citizenship education in France, Sweden, and England, 2001-2010. Education, Citizenship and Social Justice, 8(2), 215-228.

Council of Europe. (1997). Final declaration and action plan. Retrieved from https://wcd.coe.int/ViewDoc.jsp?id=593437.

Council of Europe. (1999). Declaration and programme on education for democratic citizenship, based on the rights and responsibilities of citizens. Retrieved from:

https://wcd.coe.int/ViewDoc.jsp?Ref=Decl-07.05.99/4\&Language $=$ lanEnglish\&Ver=original\&Site $=C O E \& B a c k C o l o r I n t e r n e t=D B D C F 2 \& B a c k C o l o r$ Intranet $=$ FDC864\&BackColorLogged $=$ FDC864. 
Raşit ÇELIK

Council of Europe. (2002). Presidency conclusions: Barcelona European Council 15 and 16 March 2002. Retrieved from http://www.consilium.europa.eu/ uedocs/cms_data/docs/pressdata/en/ec/71025.pdf.

Council of the European Union. (2009). Council conclusions of 12 May 2009 on a strategic framework for European cooperation in education and training ('ET 2020'). Retrieved from: http://eur-lex.europa.eu/legalcontent/EN/TXT/PDF/?uri=CELEX:52009XG0528(01)\&from=EN.

Çayır, K., \& Bağlı, M. T. (2011). 'No-one respects them anyway': Secondary school students' perception of human rights education in Turkey. Intercultural Education, 22(1), 1-14.

Çayır, K., \& Gürkaynak, İ. (2008). The state of citizenship education in Turkey:

Past and present. Journal of Social Science Education, 6(2), 50-58.

Çayır, K. (2011). Turkey's new citizenship and democracy education course: Search for democratic citizenship in a difference blind polity? Journal of Social Science Education, 10(4), 22-30.

Çelik, H. (2008). Çokkültürlülük ve Türkiye'deki görünümü [Multiculturalism and its appearance in Turkey]. Uludağ Üniversitesi Sosyal Bilimler Dergisi, 9(15), 319-332.

Çelik, S. (2012). Turkey's ministry of national education study-abroad program: Is the MoNE making the most of its investment? The Qualitative Report, 17, $1-30$.

Çelik, S. (2013). Plurilingualism, pluriculturalism, and the CEFR: Are Turkey's foreign language objectives reflected in classroom instruction? Procedia Social and Behavioral Sciences, 70, 1872-1879.

Davies, I., Evans, M., \& Reid, A. (2005). Globalising citizenship education? A critique of 'global education' and 'citizenship education'. British Journal of Educational Studies, 53(1), 66-89.

Education Council. (2001). Report from education council to the European council on the concrete future objectives of education and training systems. Retrieved from http://www.consilium.europa.eu/uedocs/cms_data/docs/pressdata/en/misc /05980.en1.html.

Elkatmış, M. (2013). 1998 Vatandaşlık ve insan hakları eğitimi programı ile 2010 vatandaşlık ve demokrasi eğitimi programlarının karşılaştırıması 
A HISTORICAL/POLITICAL JUSTIFICATION FOR THE NEED FOR MULTICULTURAL CITIZENSHIP EDUCATION AND EDUCATORS: THE CASE OF TURKEY AND THE EUROPEAN UNION

[The comparison of 1998 citizenship and human rights education syllabus and 2010 democracy education teaching program]. Ahi Evran Üniversitesi Kırşehir Eğitim Fakültesi Dergisi, 14(3), 59-74.

European Council. (2000). Presidency conclusions. Retrieved from

http://www.europarl.europa.eu/summits/lis1_en.htm.

European Council. (2010). Conclusions. Retrieved from

http://ec.europa.eu/eu2020/pdf/council_conclusion_17_june_en.pdf.

Faas, D. (2011). The nation, Europe, and migration: A comparison of geography, history, and citizenship education curricula in Greece, Germany, and England. Journal of Curriculum Studies, 43(4), 471-492.

Gelunas, A. (2015). Multilingualism as a prerequisite of intercultural education: From UNESCO programmes to sustainable development challenges of modern states. Sustainable Multilingualism, 6, 16-23.

Gök, F. (2004). Citizenship and human rights education textbooks. In D. T. Ceylan and G. Irzık (Eds.) Human rights issues in textbooks: The Turkish case (pp.108-122). Istanbul: The History Foundations of Turkey.

Green, A. (2013). Education and state formation: Europe, East Asia and the USA $\left(2^{\text {nd }}\right.$ ed). New York: Palgrave MacMillan.

Grek, S., Lawn, M., Lingard, B., Ozga, J., Rinne, R., Segerholm, C., \& Hannu, S. (2009). National policy brokering and the construction of the European education space in England, Sweden, Finland and Scotland. Comparative Education, 45(1), 5-21.

Halford, J. (2008). Hard measures for soft stuff: Citizenship indicators and educational policy under the Lisbon strategy. European Educational Research Journal, 7(3), 331-343.

Ichilov, O. (2013). Patterns of citizenship in a changing world. In O. Ichilov (Ed.), Citizenship and citizenship education in a changing world (pp. 11-27). New York: Routledge.

İnce, B. (2012). Citizenship education in Turkey: Inclusive or exclusive. Oxford Review of Education, 38(2), 115-131.

Kerr, D., \& Lopes, J. (2008). Studying civic and citizenship education in the European context. Paper presented at the annual meeting of the American educational research association, New York, USA, 24-28 March 2008. 
Keser, F., Akar, H., \& Yildirim, A. (2011). The role of extracurricular activities in active citizenship education. Journal of Curriculum Studies, 43(6), 809837.

Mann, M. (1993). Nation-states in Europe and other continents: Diversifying, developing, not dying. Daedalus, 122(3), 115-140.

Milli Eğitim Bakanlığı. (2010). İlköğretim vatandaşlık ve demokrasi dersi öğretim programı [Primary education citizenship and democracy education course instruction program]. Ankara: MEB. Retrieved from:

http://ttkb.meb.gov.tr/www/ogretim-programlari/icerik/72.

Saint-Martin, I. (2013). Teaching about religions and education in citizenship in France. Education, Citizenship and Social Justice, 8(2), 151-164.

Tambini, D. (2001). Post-national citizenship. Ethnic and Racial Studies, 4(2), 195-217.

United Nations. (1994). United Nations decade for human rights education. Retrieved from http://www.un.org/documents/ga/res/49/a49r184.htm.

Üstel, F. (2004). Makbul vatandaşın peşinde [In search of good citizen]. İstanbul: İletişim Yayınları. 


\section{Raşit Çelik}

Karadenizo technikos universitetas, Turkija; rcelik@umail.iu.edu

\section{ISTORINĖS IR POLITINĖS DAUGIAKULTŪRINIO PILIETIŠKUMO UGDYMO IR MOKYTOJU RENGIMO POREIKIO PRIEŽASTYS - TURKIJOS IR EUROPOS SAZJUNGOS ATVEJIS ${ }^{2}$}

Santrauka. Pilietiškumo ugdymas, akcentuojantis lygybę, žmogaus teises ir socialini teisinguma visiems, tapo pagrindiniu, istatymu pagristu, pasaulio piliečiu pilietiniu žiniu gerinimo ir demokratiškesnio šaliu vystymosi rẻmimo irankiu. Kaip ir dauguma kitu tautu, Turkijos Respublika, šalis, vedanti derybas su Europos Sajunga dèl galimos narystès joje, akcentuoja pilietiškumo ugdyma nuo savo susikūrimo laiku. Šiame tyrime keliamas klausimas, ar Turkija teikia tinkama pilietiškumo ugdyma, kaip jis suprantamas bei apibrezžiamas ES strategineje švietimo ir mokymo programoje (ET 2020) - ypač kalbant apie dèmesi daugiakultūriškumo ir pagarbos ivairovei skatinimui visuomeneje, kuri tampa vis labiau heterogeniška. Straipsnyje pirmiausia pateikiama bendra informacija apie pilietiškumo ugdymą Europos kontekste, atskleidžiant bendra tautiniu valstybiu ir supranacionaliniu organizaciju vystymosi eiga, ir analizuojamas pilietiškumo ugdymas šiuolaikiniame daugiakultūriniame kontekste. Tada aprašoma šiuo metu Turkijoje igyvendinama pilietiškumo sistema, kuri istoriškai teikè pirmenybę homogeniškumui, labiau akcentuodama vienybę nei ivairovę. Pabaigoje pateikiamos rekomendacijos, kodèl Turkijai svarbu plètoti daugiakultūrini pilietiškumo ugdyma ir rengti daugiakultūriškai kompetetingus mokytojus.

Pagrindinès sąvokos: Turkija, demokratijos ir pilietiškumo ugdymas, tautinè valstybė, Europos Sajunga, 2020 m. strateginè švietimo ir mokymo programa (ET 2020).

2 Dalis šio tyrimo buvo pristatyta tarptautiniame Eurazijos pedagoginiu tyrimu kongrese Stambulo Universitete, $2014 \mathrm{~m}$. balandžio 24-26 d. 